\title{
A new species of Colosmittia Andersen et Sæther from Costa Rica (Chironomidae: Orthocladiinae)
}

\author{
Trond Andersen ${ }^{1}$, Humberto Fonseca Mendes ${ }^{1,2}$ \& Linn Katrine Hagenlund ${ }^{1}$ \\ ${ }^{1}$ Department of Natural History, Bergen Museum, University of Bergen, P.b. 7800, N-5020 Bergen, Norway, \\ e-mails: trond.andersen@zmb.uib.no; linn.hagenlund@student.uib.no \\ ${ }^{2}$ Corresponding author: Humberto Fonseca Mendes, e-mail: humberto.mendes@bm.uib.no
}

ANDERSEN, T., MENDES, H.F., HAGENLUnd, L.K. A new species of Colosmittia Andersen et Sæther from Costa Rica (Chironomidae: Orthocladiinae). Biota Neotrop. 11(3): http://www.biotaneotropica.org.br/ v11n3/en/abstract?article+bn03711032011

Abstract: Colosmittia anamariae sp. n. from Costa Rica is described and figured as male imago. The genus Colosmittia Andersen et Sæther, 1994 was described based on a single species, C. clavata Andersen et Sæther, 1994 from the West Usambara Mountains in Tanzania, East Africa. A second species, C. brasileira Mendes et Andersen, 2009 was recently described from Brazil. The discovery of a third species in Costa Rica indicates that the genus might be widespread in the Neotropical region.

Keywords: Chironomidae, Orthocladiinae, Colosmittia, new species, Costa Rica.

ANDERSEN, T., MENDES, H.F., HAGENLUND, L.K. Uma nova espécie de Colosmittia Andersen et Sæther da Costa Rica (Chironomidae: Orthocladiinae). Biota Neotrop. 11(3): http://www.biotaneotropica.org.br/ v11n3/pt/abstract?article+bn03711032011

Resumo: A espécie Colosmittia anamariae sp. n., da Costa Rica, é descrita e ilustrada com base no macho adulto. O gênero Colosmittia Andersen et Sæther, 1994 foi descrito para uma única espécie, C. clavata Andersen et Sæther, 1994, de "West Usambara Mountains" na Tanzânia, leste da África e recentemente registrado para o Brasil, com a descrição de C. brasileira Mendes et Andersen, 2009. A descoberta desta espécie nova indica que o gênero Colosmittia pode estar amplamente distribuído na região Neotropical.

Palavras-chave: Chironomidae, Orthocladiinae, Colosmittia, espécie nova, Costa Rica. 


\section{Introducion}

The genus Colosmittia Andersen et Sæther was erected for C. clavata Andersen et Sæther, from the West Usambara Mountains in Tanzania, East Africa by Andersen \& Sæther (1994). Recently, Mendes \& Andersen (2009) described C. brasileira Mendes et Andersen from southeastern Brazil. The genus differs from other known orthoclads by the combination of a strongly reduced 4-segmented palp, absence of setae on squama and lack of anal point. The genus does not resemble any other described orthoclad genus and was tentatively placed in the Pseudosmittia group of genera by Andersen \& Sæther (1994).

The chironomid fauna of Central America was recently treated by Spies et al. (2009) giving a key to the genera recorded or expected in the area. However, Colosmittia was not included and will key to Pseudosmittia Edwards, 1932. The two genera can easily be separated based on the reduced palp with only 4 segments and the lack of a true anal point in Colosmittia. Below, we describe a new species of this genus, the first known record from Central America.

\section{Material and Methods}

The specimen was mounted on a slide in Canada balsam following the procedures outlined by Sæther (1969). The terminology follows Sæther (1980).

The holotype is deposited in The Natural History Collections, Bergen Museum, University of Bergen, Bergen, Norway (ZMBN).

\section{Colosmittia Andersen et Sæther}

Colosmittia Andersen et Sæther, 1994: 439.

Type species: Colosmittia clavata Andersen et Sæther, 1994: 442 , by original designation.

Other included species: Colosmittia brasileira Mendes et Andersen, 2009; Colosmittia anamariae sp. n.

Description as in Andersen \& Sæther (1994) with the following emendations: antennae with 12 or 13 flagellomeres; $\mathrm{Cu}_{1}$ curved or weakly sinuate; virga variable. Colosmittia clavata has a short, spatulate virga, while the virga in $C$. brasileira is very short and weak; the new species has a distinct needle-shaped virga.

Colosmittia anamariae sp. n. (Figures 1a-e)

Type material: Holotype male: Costa Rica, Alajuela Province, Alfaro Ruiz Cantón, near Zarcero, 15.viii.2010, net, T. Andersen, H.F. Mendes \& L.K. Hagenlund leg. (ZMBN).

Diagnostic characters: The species groups with $C$. clavata as the antennae have 12 flagellomeres. The presence of a needleshaped virga and the long second palpomere will separate it from the two previously described species.

Etymology: Named after Ana Maria Serrano Rodriguez for her hospitality during our field-work in Costa Rica.

Description: Male $(\mathrm{n}=1)$. Total length $1.51 \mathrm{~mm}$. Wing length $985 \mu \mathrm{m}$. Total length/wing length 1.53 . Wing length/length of profemur 3.06. Coloration dark brown with paler brown legs and antennae.
Head. Antenna with 12 flagellomeres; $12^{\text {th }}$ and $13^{\text {th }}$ flagellomere fused; AR 0.34; ultimate flagellomere $133 \mu \mathrm{m}$ long. Temporal setae 3 , including 1 inner vertical and 2 postorbitals. Clypeus with 5 setae. Tentorium $91 \mu \mathrm{m}$ long, $14 \mu \mathrm{m}$ wide at sieve pore. Stipes not measurable. Palp segment lengths/widths (in $\mu \mathrm{m}$ ): 11/7; $29 / 11 ; 25 / 11 ; 20 / 7$. Third palpomere with 1 sensilla subapically, $13 \mu \mathrm{m}$ long, (Figure 1a).

Thorax. Antepronotum apparently bare. Dorsocentrals 3; acrostichals 2 very weak in mid scutum; prealar 1 . Scutellum with 2 setae.

Wing (Figure 1b). VR 1.54. Costal extension $52 \mu \mathrm{m}$ long, false vein extending to $159 \mu \mathrm{m} . \mathrm{Cu}_{1}$ sinuate. Brachiolum with 1 seta; $\mathrm{R}$ with 1 strong seta, remaining veins and cells bare. Squama bare.

Legs. Spur of foretibia $23 \mu \mathrm{m}$ long; spurs of midtibia 18 and $14 \mu \mathrm{m}$ long; hind leg lost. Width at apex of foretibia $20 \mu \mathrm{m}$, of midtibia $20 \mu \mathrm{m}$. Lengths (in $\mu \mathrm{m}$ ) and proportions of legs as in Table 1.

Hypopygium (Figures 1c-e). Tergite IX with 4 weak setae; laterosternite IX with 2 strong setae. Phallapodeme $56 \mu \mathrm{m}$ long; transverse sternapodeme $69 \mu \mathrm{m}$ long. Virga composed of a needle-like spine, $12 \mu \mathrm{m}$ long. Gonocoxite $107 \mu \mathrm{m}$ long; inferior volsella rounded, $20 \mu \mathrm{m}$ long, reaching 0.66 of gonocoxite length. Gonostylus $62 \mu \mathrm{m}$ long; megaseta $4 \mu \mathrm{m}$ long. HR 1.71, HV 2.43.

\section{Habitat}

The species was collected with a hand net at about $1500 \mathrm{~m}$ altitude in a mountainous area with steep hillsides. The mountains are covered with secondary cloud forest and farmland and a few trickles and seeps are found near the collecting site. The area is very humid, the trees are covered with mosses and epiphytes, and many bromeliad species were growing on the ground, some native, some introduced. Most days during the field work in early to mid August the sun was shining during early morning and orthoclads would swarm above the vegetation. At about 10:00 am it started to get foggy and within an hour it would rain, the temperature dropped and the chironomids stopped swarming.

\section{Discussion}

As pointed out by Mendes \& Andersen (2009), Colosmittia might be the first Ortholadiinae genus to demonstrate an Afro-Brazilian vicariance pattern. Colosmittia clavata Andersen et Sæther, 1994 was described from the West Usambara Mountains in Tanzania, East Africa, while C. brasileira Mendes et Andersen, 2009 was recently described from Brazil. The discovery of a third species in Costa Rica indicates that the genus might be widespread in the Neotropical region.

\section{Acknowledgements}

We are greatly indebted to Dr. Manuel A. Zumbado, Instituto Nacional de Biodiversidad, San Jose, Costa Rica for sampling authorizations, and to Paulo Chavarría Serrano for assistance while in Costa Rica. Gladys Ramirez made the slide preparation.

Table 1. Lengths (in $\mu \mathrm{m})$ and proportions of legs of Colosmittia anamariae $\mathrm{n}$. sp., male $(\mathrm{n}=1)$.

\begin{tabular}{|c|c|c|c|c|c|c|c|c|c|c|c|}
\hline & fe & ti & $\mathrm{ta}_{1}$ & $\mathrm{ta}_{2}$ & $\mathbf{t a}_{3}$ & $\mathrm{ta}_{4}$ & $\mathrm{ta}_{5}$ & $\mathbf{L R}$ & BV & SV & BR \\
\hline $\mathrm{p}_{1}$ & 328 & 367 & 119 & 61 & 45 & 28 & 20 & 0.32 & 5.26 & 5.85 & 3.0 \\
\hline $\mathrm{p}_{2}$ & 223 & 259 & 83 & 38 & 29 & 19 & 17 & 0.32 & 5.41 & 5.83 & 2.9 \\
\hline $\mathrm{p}_{3}$ & - & - & - & - & - & - & - & - & - & - & - \\
\hline
\end{tabular}




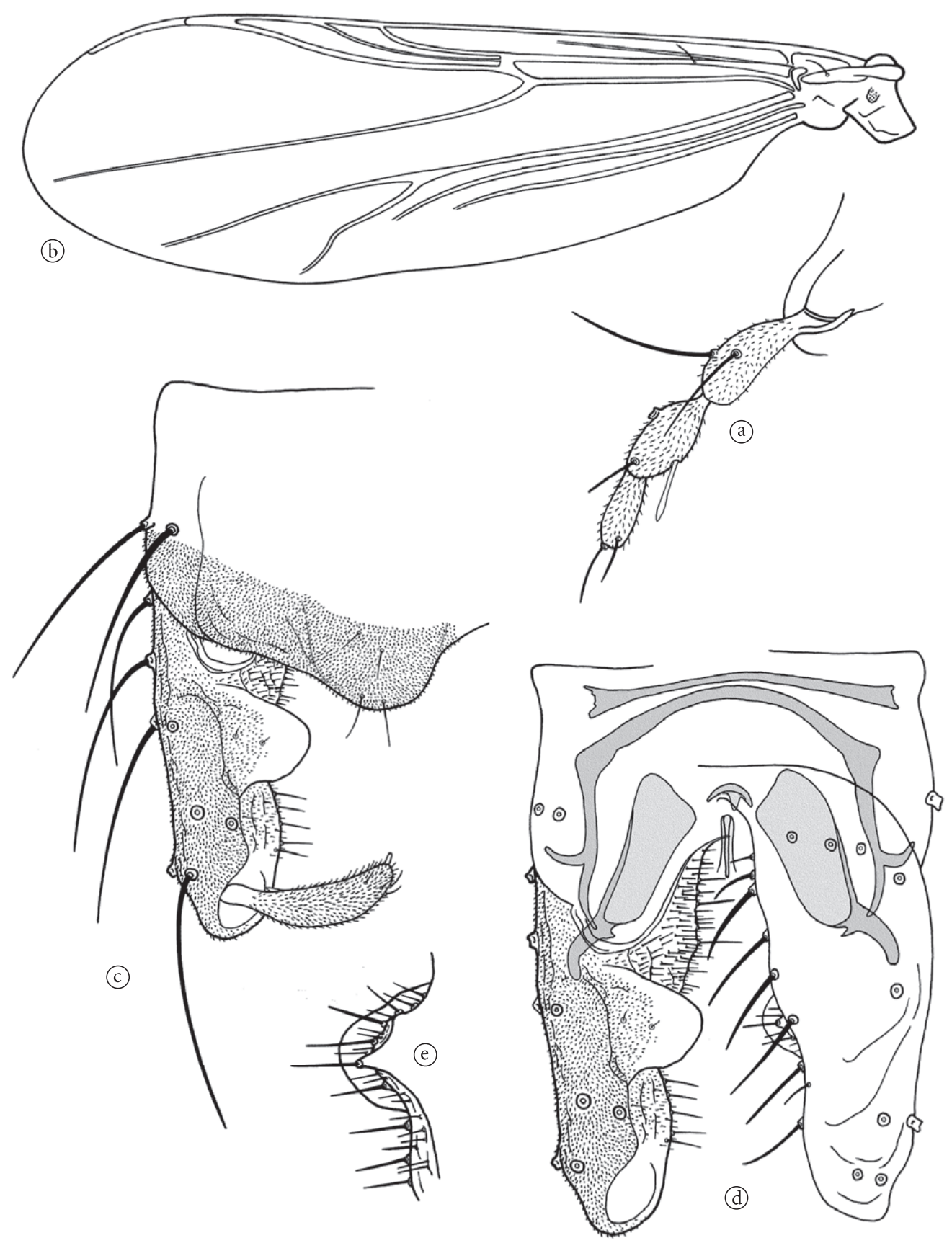

Figures 1. Colosmittia anamariae sp. n., male. a) palp; b) wing; c) hypopygium, dorsal view; d) hypopygium with tergite IX removed, left dorsal aspect, right ventral aspect; e) inferior volsella, ventral view.

\section{References}

ANDERSEN, T. \& SÆTHER, O.A. 1994. Colosmittia clavata gen. n., sp. n., a new orthoclad from the West Usambara Mountains, Tanzania (Diptera: Chironomidae). J. Kans. Entomol. Soc. 66:439-443.

MENDES, H.F. \& ANDERSEN, T. 2009. First record of the genus Colosmittia Andersen \& Sæther (Chironomidae: Orthocladiinae) from the Neotropical Region. Neotrop. Entomol. 38:649-652. PMid:19943014. http://dx.doi. org/10.1590/S1519-566X2009000500014
SÆTHER, O.A. 1969. Some Nearctic Podonominae, Diamesinae and Orthocladiinae (Diptera: Chironomidae). Bull. Fish. Res. Bd Canada 107:1-154.

SÆTHER, O.A. 1980. Glossary of Chironomid morphology terminology (Diptera: Chironomidae). Entomol. Scand., Suppl. 14:1-51.

SPIES, M., ANDERSEN, T., EPLER, J.H. \& WATSON JUNIOR, C.N. 2009. Chironomidae (Non-biting midges). In Manual of Central American Diptera (B.V. Brown, A. Borkent, J.M. Cumming, D.M. Wood, N.E. Woodley \& M. Zumbado, eds.). NRC Research Press, Ottawa, Ontario, Canada, p.437-480. 